\title{
Article \\ Genome Size Dynamics in Marine Ribbon Worms (Nemertea, Spiralia)
}

\author{
Juraj Paule ${ }^{1}$, Jörn von Döhren ${ }^{2}$, Christina Sagorny ${ }^{2}$ and Maria A. Nilsson ${ }^{3,4, *}$ \\ 1 Department of Botany and Molecular Evolution, Senckenberg Research Institute and Natural History \\ Museum Frankfurt, Senckenberganlage 25, D-60325 Frankfurt am Main, Germany; \\ juraj.paule@senckenberg.de \\ 2 Institute of Evolutionary Biology and Ecology, University of Bonn, An der Immenburg 1, \\ D-53121 Bonn, Germany; jdoehren@evolution.uni-bonn.de (J.v.D.); csagorny@evolution.uni-bonn.de (C.S.) \\ 3 Senckenberg Biodiversity and Climate Research Centre, Senckenberganlage 25, \\ D-60325 Frankfurt am Main, Germany \\ 4 LOEWE Centre for Translational Biodiversity Genomics (LOEWE-TBG), Senckenberganlage 25, \\ D-60325 Frankfurt am Main, Germany \\ * Correspondence: maria.nilsson-janke@senckenberg.de
}

Citation: Paule, J.; von Döhren, J.; Sagorny, C.; Nilsson, M.A. Genome Size Dynamics in Marine Ribbon Worms (Nemertea, Spiralia). Genes 2021, 12, 1347. https://doi.org/ $10.3390 /$ genes12091347

Academic Editor: Joong-Ki Park

Received: 13 July 2021

Accepted: 26 August 2021

Published: 28 August 2021

Publisher's Note: MDPI stays neutral with regard to jurisdictional claims in published maps and institutional affiliations.

Copyright: (c) 2021 by the authors. Licensee MDPI, Basel, Switzerland. This article is an open access article distributed under the terms and conditions of the Creative Commons Attribution (CC BY) license (https:/ / creativecommons.org/licenses/by/ $4.0 /)$.

\begin{abstract}
Nemertea is a phylum consisting of 1300 mostly marine species. Nemertea is distinguished by an eversible muscular proboscis, and most of the species are venomous. Genomic resources for this phylum are scarce despite their value in understanding biodiversity. Here, we present genome size estimates of Nemertea based on flow cytometry and their relationship to different morphological and developmental traits. Ancestral genome size estimations were done across the nemertean phylogeny. The results increase the available genome size estimates for Nemertea three-fold. Our analyses show that Nemertea has a narrow genome size range (0.43-3.89 pg) compared to other phyla in Lophotrochozoa. A relationship between genome size and evolutionary rate, developmental modes, and habitat was found. Trait analyses show that the highest evolutionary rate of genome size is found in upper intertidal, viviparous species with direct development. Despite previous findings, body size in nemerteans was not correlated with genome size. A relatively small genome $(1.18 \mathrm{pg})$ is assumed for the most recent common ancestor of all extant nemerteans. The results provide an important basis for future studies in nemertean genomics, which will be instrumental to understanding the evolution of this enigmatic and often neglected phylum.
\end{abstract}

Keywords: C-value; genome size; flow cytometry; habitat; life history; ribbon worm; Nemertea; Lophotrochozoa; evolution; taxonomy

\section{Introduction}

Nemertea (ribbon worms) is a clade of worm-shaped animals comprising approximately 1300 species, with close phylogenetic affinities to Lophotrochozoa [1-3]. The species cover a large-size spectrum from several millimeters in interstitial species up to 30 meters in Lineus longissimus (Gunnerus, 1770) [4,5]. Most nemerteans are predators that hunt their prey with an eversible muscular proboscis that is housed in the rhynchocoel, which is a fluid-filled secondary body cavity situated dorsal to the intestine. The most species-rich lineage within Nemertea are Hoplonemertea that possess a proboscis that is armed with one large (Monostilifera) or several smaller (Polystilifera) calcareous stylets [6]. Another commonly encountered clade, Pilidiophora, is characterized by a unique, helmet-shaped larval type, the pilidium $[7,8]$. Within Pilidiophora, most species are known from the clade Heteronemertea [6]. Together, Hoplonemertea and Pilidiophora comprise a monophyletic lineage termed Neonemertea $[9,10]$. Palaeonemertea, as currently defined, represents a third clade comprising morphologically diverse species that is sister to Neonemertea [10-12]. 
Despite the relatively small number of species comprising Nemertea, there is considerable diversity with respect to ecology, reproductive biology, and development. The majority of nemertean species are benthic, with the most comprehensive distribution records being available for species occurring in shallow subtidal and intertidal to supralittoral, almost semi-terrestrial habitats [6]. Within Pilidiophora and Hoplonemertea, there are several freshwater species, whereas the few fully terrestrial species are restricted to the monostiliferan clade of Hoplonemertea [6]. Nemerteans are generally gonochoristic, but some hermaphroditic species exist, especially among the non-marine neonemerteans [13]. For sexual reproduction, the vast majority of nemertean species shed eggs into the surrounding sea water, which is followed by external fertilization. However, in several species, mucus spawning, internal fertilization, and viviparity have evolved $[7,8,13,14]$. The viviparous hoplonemertean species are assumed to show internal fertilization [13]. Very few species seem to have abolished sexual reproduction on a regular basis and largely reproduce by fissiparity, i.e., spontaneous fragmentation and subsequent complete regeneration of the fragments [15]. In most species, the fertilized eggs develop into free-swimming larvae that have to feed to proceed in their development [8]. The pilidium, the eponymous larval type of Pilidiophora, is such a pelagic, planktotrophic larval type $[7,8,14]$. In Hoplonemertea, the larval type has been termed decidula, whereas in palaeonemertean species, the larva has been termed planuliform larva $[7,8,14]$. In all major lineages, pelagic but non-feeding (lecithotrophic) larvae have evolved (reviewed in [14]). Furthermore, in Hoplonemertea and Pilidiophora, there are species in which no swimming larval stages are present, and development is confined to the clutch (intracapsular development) (reviewed in $[7,8,14])$. However, even within the clutch, the pilidiophoran species with intracapsular development have retained some characteristics of larval development also found in the free-swimming pilidium of their relatives [16]. Such intracapsular larvae of Pilidiophora have been termed Desor larvae and either feed on sibling eggs and embryos within the same clutch (ootrophic or adelphopagic, respectively), such as in Lineus ruber (Müller, 1774), or are truly non-feeding (i.e., lecithotrophic), such as in Lineus viridis (Müller, 1774) (reviewed in $[7,8,14,16]$.

Variation in genome size is generated by three principal mechanisms: polyploidization, deletion or proliferation of DNA, and gain or loss of single chromosomes (i.e., aneuploidy). However, the universal controlling factors for the size of genomes across species are unknown, and different hypotheses concerning the mechanisms of genome size evolution have been postulated (e.g., [17]). Although several theories suggest neutral mechanisms such as population size influence (e.g., [18]) or mutational equilibrium due to the imbalance in indels (e.g., [19-22]), adaptive hypotheses of genome size evolution have also been considered [23,24]. Interestingly, altered genome sizes may have substantial consequences at a cellular, tissue, and organismal level and possibly influence metabolic and ecological features, which provides useful insights for the understanding of evolution and diversification (e.g., $[20,25,26])$.

The basic genomic characteristics of nemerteans, such as chromosome numbers, have been studied already since the end of the 19th century, but only a few data for a limited number of species have been accumulated since then (reviewed by [27]). In Heteronemertea, it was shown that there is considerable variation in chromosome numbers ranging from $2 n=4$ to $2 n=56$ showing signatures of polyploidy (e.g., Lineus sanguineus (Rathke, 1799)/Lineus lacteus (Rathke, 1843)) or aneu-/dysploidy (L. ruber) [27,28]. Moreover, certain variation in chromosome sizes was also demonstrated [27]. Therefore, it was surprising that the only study on genome size variation in Nemertea revealed relatively low variation $(1 \mathrm{C}=0.28-1.17 \mathrm{pg})$, even though species from all three major phylogenetic lineages were analyzed [29]. The highest genome size diversity within nemertean clades was documented for Heteronemertea covering four representatives of the polyphyletic genus Micrura Ehrenberg, 1828 [11,12,15]. Hoplonemertea was represented by early diverging Nipponnemertes bimaculata (Coe, 1901) and two species of Paranemertes Coe, 1901 in a more derived phylogenetic position [9]. The Palaeonemertea, which exhibits the most 
pronounced morphological diversity within Nemertea (e.g., [30] for spermatozoa; [30] for nephridia), was only represented by Tubulanus polymorphus Renier, 1804 from the Pacific coast of the USA [29]. Hence, the studied taxa covered only about $0.3 \%$ of the described nemertean diversity $[1,3]$. Moreover, the ecological and developmental diversity was not covered in detail, as all investigated species are found in mid-intertidal or subtidal habitats [29]. With two exceptions representing lecithotrophic larvae, Micrura verrilli Coe, 1901 and T. polymorphus [8,31], most of the other included species exhibit development with a feeding pilidium larva in Heteronemertea and a decidula larva in Monostilifera [8,32-34], although no information is published for Paranemertes sanjuanensis Stricker, 1982, N. bimaculata, and Notospermus geniculatus (Delle Chiaje, 1828) [29,35,36]. Nevertheless, a significant positive correlation was found between genome size and mid-range body length across the studied species [29], which is interesting, as long body size is typical in Nemertea (e.g., L. longissimus, see [4]).

By adding new data, covering morphologically divergent lineages, such as Cephalotrichidae as well as known ecological and developmental variation of the phylum [14,37-44], we aimed to (1) analyze the distribution and potential evolutionary consequences of genome size variation in the phylum Nemertea. More specifically, within a novel phylogenetic framework, we aimed to (2) test the correlation of body length and genome size as well as (3) relate genome size to habitat and several functional and developmental traits.

\section{Materials and Methods}

\subsection{Nemertean Species Selection}

Nemerteans were collected in the vicinity of Concarneau and Roscoff, France, during several field trips from 2018 to 2020. A list of studied samples, geographic origin, and collection history is provided in Supplementary Table S1. After collection, the animals were kept in sea water from the locality and stored at $12{ }^{\circ} \mathrm{C}$. In total, the genome sizes of 18 nemertean species were estimated (Table 1). This included four representatives of Paleonemertea, five representatives of Hoplonemertea, and nine heteronemerteans. Due to the few distinguishing outer morphological characters, the mitochondrial COI (cytochrome C oxidase subunit I) gene was sequenced for all specimens, or conspecifics from the same locality, and compared to published sequences (see Section 2.3). Species identified by COI barcoding as well as species identified by morphological characters are listed in Supplementary Table S1, together with the GenBank reference to the corresponding COI barcode. In addition, six morphological, ecological, reproductive, and developmental traits for studied taxa were extracted from published literature or personal observations and are given in Supplementary Table S2.

\subsection{Genome Size Estimation}

Genome size (2C-value, [45]) was estimated by flow cytometry using the Partec CyFlow Space (Partec, Münster, Germany) equipped with a green solid-state laser. Sample preparation followed the two-step Otto protocol [46] with an internal standard Glycine max cv. Polanka $(2 \mathrm{C}=2.50 \mathrm{pg}$, [47]) or Pisum sativum L. cv. Ctirad (2C $=9.09 \mathrm{pg}$, [48]). Nemertean tissue was mixed with the leaf tissue of the internal reference standard and homogenized with a razor blade in a Petri dish containing $1 \mathrm{~mL}$ of ice-cold Otto I buffer $(0.1 \mathrm{M}$ citric acid, $0.5 \%$ Tween 20, [46]). The suspension was filtered through a $42 \mu \mathrm{m}$ nylon mesh and incubated for approximately $15 \mathrm{~min}$ at room temperature. The staining solution consisted of $1 \mathrm{~mL}$ of Otto II buffer (0.4 M Na $2 \mathrm{HPO}_{4} \cdot 12 \mathrm{H}_{2} \mathrm{O}$ ), $\beta$-mercaptoethanol (final concentration of $2 \mu \mathrm{L} / \mathrm{mL}$ ), intercalating fluorochrome propidium iodide (PI), and RNase IIA (both at final concentrations of $50 \mu \mathrm{g} / \mathrm{mL}$ ). Fluorescence was induced by a $30 \mathrm{~mW}$ green solid-state laser $(532 \mathrm{~nm}$ ) and fluorescence intensities of 10,000-15,000 nuclei per measurement were recorded. Sample/standard ratios were calculated from the means of the sample and standard fluorescence histograms, and only histograms with coefficients of variation $<5 \%$ for the $G_{0} / G_{1}$ sample peak were considered. Two to nine replicate measurements of each sample were carried out on different days in order to account for between-day variation caused 
by random instrument drift and / or non-identical sample preparation. The $2 \mathrm{C}$ values in picograms were also converted to $1 \mathrm{C}$ values in base pairs (1 pg = 978 Mb [49]). Additional genome size estimates for nemerteans were excerpted from two publications [29,50], data from other representatives of Lophotrochozoa were extracted from the Animal Genome Size Database and multiplied by 2 in order to get $2 C$ values [51], which were used for further statistical analyses. The genome size of Cerebratulus lacteus (Leidy, 1851) $(1 \mathrm{C}=1.40 \mathrm{pg})$ was not included due to missing details of the estimation method [52].

\subsection{DNA Isolation, PCR, Sequencing, and Phylogenetic Reconstruction}

DNA was isolated from flash-frozen individuals using the Qiagen DNeasy Blood $\&$ Tissue Kit according to the manufacturer's instructions. The mitochondrial COI gene was amplified with the primers LCO1490 and HCO2198 [53]. The resulting PCR products were sequenced from both strands on an ABI sequencer 3730 DNA analyzer (Applied Biosystems, Foster City, USA) by the laboratory center of the Senckenberg Biodiversity and Climate Research Centre Frankfurt (SBiK-F) or by LGC Genomics (Berlin, Germany) with the primers used for the PCR. COI sequences of additional species were downloaded from GenBank and aligned with MUSCLE [54] in AliView v1.26 [55] and inspected manually. IQ-TREE v1.6.12 with the implemented ModelFinder was used to build a maximum likelihood (ML) phylogeny [56-58] in order to identify the closest relative for each species and reconstruct a phylogenetic tree. Due to the short length of the partial COI gene and deep divergences of the included species, ML analyses were carried out for each of the three nemertean groups separately. The resulting trees were inspected and used to manually build a consensus phylogeny that conforms to previously published hypotheses based on larger datasets $[10,15]$. The topology was rooted at Palaeonemertea and consistent with previous phylogenies [10].

\subsection{Data Analyses}

Statistical analyses were performed in R v4.0.2 [59], and data were visualized as boxplots. The relationship between chromosome counts and $2 \mathrm{C}$ values was assessed by Pearson's correlation coefficient. Comparative analyses were performed in R using phytools v0.6-60 [60] and OUwie v2.3 [61] using the consensus nemertean phylogenetic tree as mentioned above. The differences in genome size among different lineages or different ecological and developmental types were assessed by Kruskal-Wallis test as well as phylANOVA in phytools. To determine whether rates of genomic characters' evolution differ among nemerteans from different habitats or possessing different functional/developmental traits, the fit of two Brownian motion (BM) and five Ornstein-Uhlenbeck (OU) models was compared using OUwie. Both BM and OU models estimate the rate of stochastic motion $\left(\sigma^{2}\right)$. The OU process allows the trait to fluctuate around an optimum value $(\theta)$ in parameter space with a strength of attraction $(\alpha)$ toward that optimum, while BM allows the trait to move equally to any parameter space. Models BM1 and BMS assign single and multiple rates $\left(\sigma^{2}\right)$ of random drift. OU1 and OUM model single and multiple optima $(\theta)$ for different clades with a single $\alpha$ and $\sigma^{2}$. The remaining models assume either multiple $\sigma^{2}$ (OUMV), multiple $\alpha$ (OUMA), or both (OUMVA) among clades. When fitting models using OUwie, the starting value $\theta_{0}$ was dropped from the model and assumed to be distributed according to the stationary distribution of the OU process (default setting). The performance of each model was assessed by (1) confirming that the eigenvalues of the Hessian matrix were positive [61] and (2) checking that the estimated optima $(\theta)$ of traits were not outside a plausible range. Only models passing these criteria were retained. The best-fitting model was selected using AIC weights based on the sample size-corrected Akaike information criterion (AICc) using the function aic.w in phytools.

Relationships between genome size and body length and width were evaluated by multiple phylogenetic generalized least-squares (PGLS) [62]. The PGLS analyses were carried out using the R package caper v1.0.1 [63] with the $\lambda$ value estimated by maximum likelihood. The ancestral states of $2 \mathrm{C}$-value were reconstructed using the maximum like- 
lihood estimation (function fastAnc) and visualized on the phylogenetic tree using the function contMap in phytools.

\section{Results}

The new genome size estimates of 18 Nemertea species are listed along with the nine published values (Table 1) $[29,50]$. The new estimates show that the $2 \mathrm{C}$ values in Nemertea range between $0.43 \mathrm{pg}$ in Emplectonema gracile (Johnston, 1837) (Hoplonemertea: Monostilifera) and $3.89 \mathrm{pg}$ in Lineus acutifrons Southern, 1913 (Pilidiophora: Heteronemertea).

Table 1. Genome sizes in Nemertea. Previously published $1 \mathrm{C}$ data by $[29,50]$ were multiplied by two in order to get $2 \mathrm{C}$. For the recalculation, the formula $1 \mathrm{pg}=978 \mathrm{Mbp}$ by [49] was applied.

\begin{tabular}{|c|c|c|c|c|c|c|c|c|}
\hline Species & Order:Class & Method & Standard & $2 \mathrm{C}$ [pg] & $\pm \mathbf{S D}$ & 1C [Mbp] & \pm SD & Source \\
\hline $\begin{array}{l}\text { Amphiporus lactifloreus } \\
\text { (Johnston, 1828) }\end{array}$ & $\begin{array}{l}\text { Hoplonemertea: } \\
\text { Monostilifera }\end{array}$ & FCM & G. $\max$ & 1.18 & 0.01 & 575.78 & 6.13 & this study \\
\hline $\begin{array}{c}\text { Carinina ochracea } \\
\text { [38] }\end{array}$ & $\begin{array}{l}\text { Palaeonemertea: } \\
\text { Tubulaniformes }\end{array}$ & FCM & G. $\max$ & 0.54 & 0.00 & 264.88 & 1.03 & this study \\
\hline $\begin{array}{c}\text { Cephalothrix hermaphroditicus } \\
\text { Gibson, Sanchez, and } \\
\text { Mendez, } 1990\end{array}$ & $\begin{array}{l}\text { Palaeonemertea: } \\
\text { Archinemertea }\end{array}$ & FCM & G. $\max$ & 1.73 & 0.01 & 847.72 & 4.31 & this study \\
\hline $\begin{array}{l}\text { Cephalothrix oestrymnicus } \\
\text { Junoy and Gibson, } 1991\end{array}$ & $\begin{array}{l}\text { Palaeonemertea: } \\
\text { Archinemertea }\end{array}$ & FCM & G. $\max$ & 1.32 & 0.03 & 646.34 & 12.24 & this study \\
\hline $\begin{array}{l}\text { Cerebratulus marginatus } \\
\text { Renier, } 1804\end{array}$ & $\begin{array}{l}\text { Pilidiophora: } \\
\text { Heteronemertea }\end{array}$ & FCM & O. mykiss & 2.34 & 0.06 & 1144.26 & 29.34 & [29] \\
\hline $\begin{array}{l}\text { Emplectonema gracile } \\
\text { (Johnston, 1837) }\end{array}$ & $\begin{array}{l}\text { Hoplonemertea: } \\
\text { Monostilifera }\end{array}$ & FCM & G. $\max$ & 0.43 & 0.01 & 209.75 & 5.42 & this study \\
\hline $\begin{array}{l}\text { Lineus acutifrons } \\
\text { Southern, } 1913\end{array}$ & $\begin{array}{l}\text { Pilidiophora: } \\
\text { Heteronemertea }\end{array}$ & $\mathrm{FCM}$ & G. $\max$ & 3.89 & 0.13 & 1904.45 & 64.20 & this study \\
\hline $\begin{array}{l}\text { Lineus clandestinus } \\
\text { Krämer, Schmidt, } \\
\text { Podsiadlowski, Beckers, } \\
\text { Horn and von Döhren, } 2016\end{array}$ & $\begin{array}{l}\text { Pilidiophora: } \\
\text { Heteronemertea }\end{array}$ & FCM & P. sativum & 2.91 & 0.10 & 1423.91 & 51.16 & this study \\
\hline $\begin{array}{l}\text { Lineus lacteus } \\
\text { (Rathke, 1843) }\end{array}$ & $\begin{array}{l}\text { Pilidiophora: } \\
\text { Heteronemertea }\end{array}$ & FCM & G. $\max$ & 0.97 & 0.02 & 474.88 & 10.66 & this study \\
\hline $\begin{array}{l}\text { Lineus longissimus } \\
\text { (Gunnerus, 1770) }\end{array}$ & $\begin{array}{l}\text { Pilidiophora: } \\
\text { Heteronemertea }\end{array}$ & FCM & G. $\max$ & 0.98 & 0.04 & 477.06 & 17.58 & this study \\
\hline Lineus ruber (Müller, 1774) & $\begin{array}{c}\text { Pilidiophora: } \\
\text { Heteronemertea }\end{array}$ & FCM & P. sativum & 2.75 & 0.04 & 1342.41 & 19.59 & this study \\
\hline $\begin{array}{l}\text { Lineus sanguineus } \\
\text { (Rathke, 1799) }\end{array}$ & $\begin{array}{l}\text { Pilidiophora: } \\
\text { Heteronemertea }\end{array}$ & FCM & G. $\max$ & 1.17 & 0.03 & 572.93 & 13.05 & this study \\
\hline Lineus viridis (Müller, 1774) & $\begin{array}{l}\text { Pilidiophora: } \\
\text { Heteronemertea }\end{array}$ & FCM & P. sativum & 2.20 & 0.05 & 1074.02 & 25.35 & this study \\
\hline $\begin{array}{c}\text { Maculaura alaskensis } \\
\text { (Coe, 1901) (published as } \\
\text { Micura alaskensis) }\end{array}$ & $\begin{array}{l}\text { Pilidiophora: } \\
\text { Heteronemertea }\end{array}$ & FCM & O. mykiss & 0.82 & NA & 400.98 & NA & [29] \\
\hline $\begin{array}{l}\text { Micrura purpurea } \\
\text { (Dalyell, 1853) }\end{array}$ & $\begin{array}{l}\text { Pilidiophora: } \\
\text { Heteronemertea }\end{array}$ & $\mathrm{FCM}$ & G. $\max$ & 1.24 & 0.02 & 606.21 & 9.81 & this study \\
\hline Micrura verrilli Coe, 1901 & $\begin{array}{c}\text { Pilidiophora: } \\
\text { Heteronemertea }\end{array}$ & FCM & O. mykiss & 1.10 & NA & 537.90 & NA & [29] \\
\hline Micrura wilsoni (Coe, 1904) & $\begin{array}{l}\text { Pilidiophora: } \\
\text { Heteronemertea }\end{array}$ & FCM & O. mykiss & 1.16 & NA & 567.24 & NA & [29] \\
\hline
\end{tabular}


Table 1. Cont.

\begin{tabular}{|c|c|c|c|c|c|c|c|c|}
\hline Species & Order:Class & Method & Standard & 2C [pg] & $\pm \mathrm{SD}$ & 1C $[\mathrm{Mbp}]$ & $\pm \mathbf{S D}$ & Source \\
\hline $\begin{array}{c}\text { Nipponnemertes bimaculata } \\
\text { (Coe, 1901) } \\
\text { (published as } N . \\
\text { bimaculatus) }\end{array}$ & $\begin{array}{l}\text { Hoplonemertea: } \\
\text { Monostilifera }\end{array}$ & FCM & O. mykiss & 1.14 & 0.02 & 557.46 & 9.78 & [29] \\
\hline $\begin{array}{l}\text { Notospermus geniculatus } \\
\text { (Delle Chiaje, 1828) }\end{array}$ & $\begin{array}{c}\text { Pilidiophora: } \\
\text { Heteronemertea }\end{array}$ & k-mer & NA & 1.75 & NA & 859.00 & NA & [50] \\
\hline $\begin{array}{c}\text { Paranemertes peregrina } \\
\text { Coe, } 1901\end{array}$ & $\begin{array}{l}\text { Hoplonemertea: } \\
\text { Monostilifera }\end{array}$ & FCM & O. mykiss & 0.58 & 0.00 & 283.62 & 0.00 & [29] \\
\hline $\begin{array}{c}\text { Paranemertes sanjuanensis } \\
\text { Stricker, } 1982\end{array}$ & $\begin{array}{l}\text { Hoplonemertea: } \\
\text { Monostilifera }\end{array}$ & FCM & O. mykiss & 0.56 & 0.16 & 273.84 & 78.24 & [29] \\
\hline $\begin{array}{l}\text { Prosorhochmus claparedii } \\
\text { Keferstein, } 1862\end{array}$ & $\begin{array}{l}\text { Hoplonemertea: } \\
\text { Monostilifera }\end{array}$ & FCM & G. $\max$ & 3.68 & 0.10 & 1801.70 & 50.97 & this study \\
\hline $\begin{array}{l}\text { Prosorhochmus delagei } \\
\text { Oxner, } 1907\end{array}$ & $\begin{array}{l}\text { Hoplonemertea: } \\
\text { Monostilifera }\end{array}$ & FCM & P. sativum & 1.29 & 0.02 & 631.60 & 11.34 & this study \\
\hline $\begin{array}{c}\text { Riseriellus occultus } \\
\text { Rogers, Junoy, Gibson, and } \\
\text { Thorpe, } 1993\end{array}$ & $\begin{array}{l}\text { Pilidiophora: } \\
\text { Heteronemertea }\end{array}$ & FCM & G. $\max$ & 1.44 & 0.02 & 706.15 & 10.34 & this study \\
\hline $\begin{array}{l}\text { Tetrastemma melanocephalum } \\
\text { (Johnston, 1837) }\end{array}$ & $\begin{array}{l}\text { Hoplonemertea: } \\
\text { Monostilifera }\end{array}$ & FCM & G. $\max$ & 1.34 & 0.04 & 657.40 & 18.19 & this study \\
\hline $\begin{array}{l}\text { Tubulanus polymorphus } \\
\text { Renier, } 1804 \text { (Atlantic) }\end{array}$ & $\begin{array}{l}\text { Palaeonemertea: } \\
\text { Tubulaniformes }\end{array}$ & FCM & G. $\max$ & 0.73 & 0.02 & 358.47 & 11.80 & this study \\
\hline $\begin{array}{l}\text { Tubulanus polymorphus } \\
\text { Renier, } 1804 \text { (Pacific) }\end{array}$ & $\begin{array}{l}\text { Palaeonemertea: } \\
\text { Tubulaniformes }\end{array}$ & FCM & O. mykiss & 0.64 & 0.08 & 312.96 & 39.12 & [29] \\
\hline
\end{tabular}

Compared to other representatives of Lophotrochozoa, Nemertea display a relatively narrow genome size range, about the same as Ectoprocta (Bryozoa), which range from 0.4 to $3.2 \mathrm{pg}$ but are larger than in Brachiopoda (0.62 to $0.92 \mathrm{pg}$ ) (Figure 1). The $2 \mathrm{C}$ of the largest molluscan genome is $15.7 \mathrm{pg}$, whereas the $2 \mathrm{C}$ of the largest annelid genome is $15.28 \mathrm{pg}$.

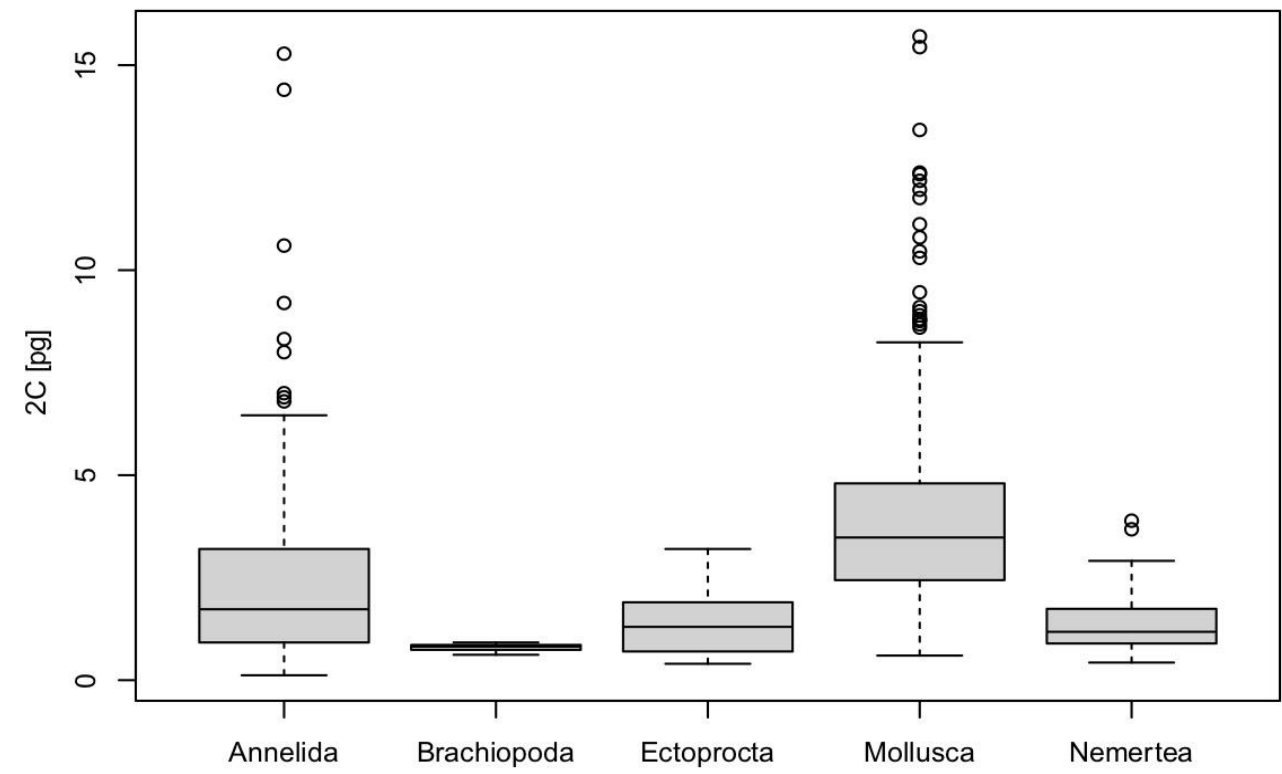

Figure 1. Boxplots of genome sizes across different lineages of Lophotrochozoa.

Within Nemertea, the largest genome size range was observed in Hoplonemertea, closely followed by Pilidiophora. Palaeonemertea exhibits the narrowest $2 \mathrm{C}$ interval 
ranging from 0.54 pg (Carinina ochracea Sundberg, Chernyshev, Kajihara, Kånneby, and Strand, 2009) to $1.73 \mathrm{pg}$ (Cephalothrix hermaphroditicus (Gibson, Sanchez, and Mendez, 1990)) (Figures 2 and 3). Nevertheless, as shown by a Kruskall-Wallis test as well as phylogenetic ANOVA, the differences observed among the nemertean lineages are not statistically significant ( $p=0.156$ and $p=0.813$, respectively). Using fastANC, the ancestral 2C genome size for Nemertea was $1.18 \mathrm{pg}$ (Figure 2).

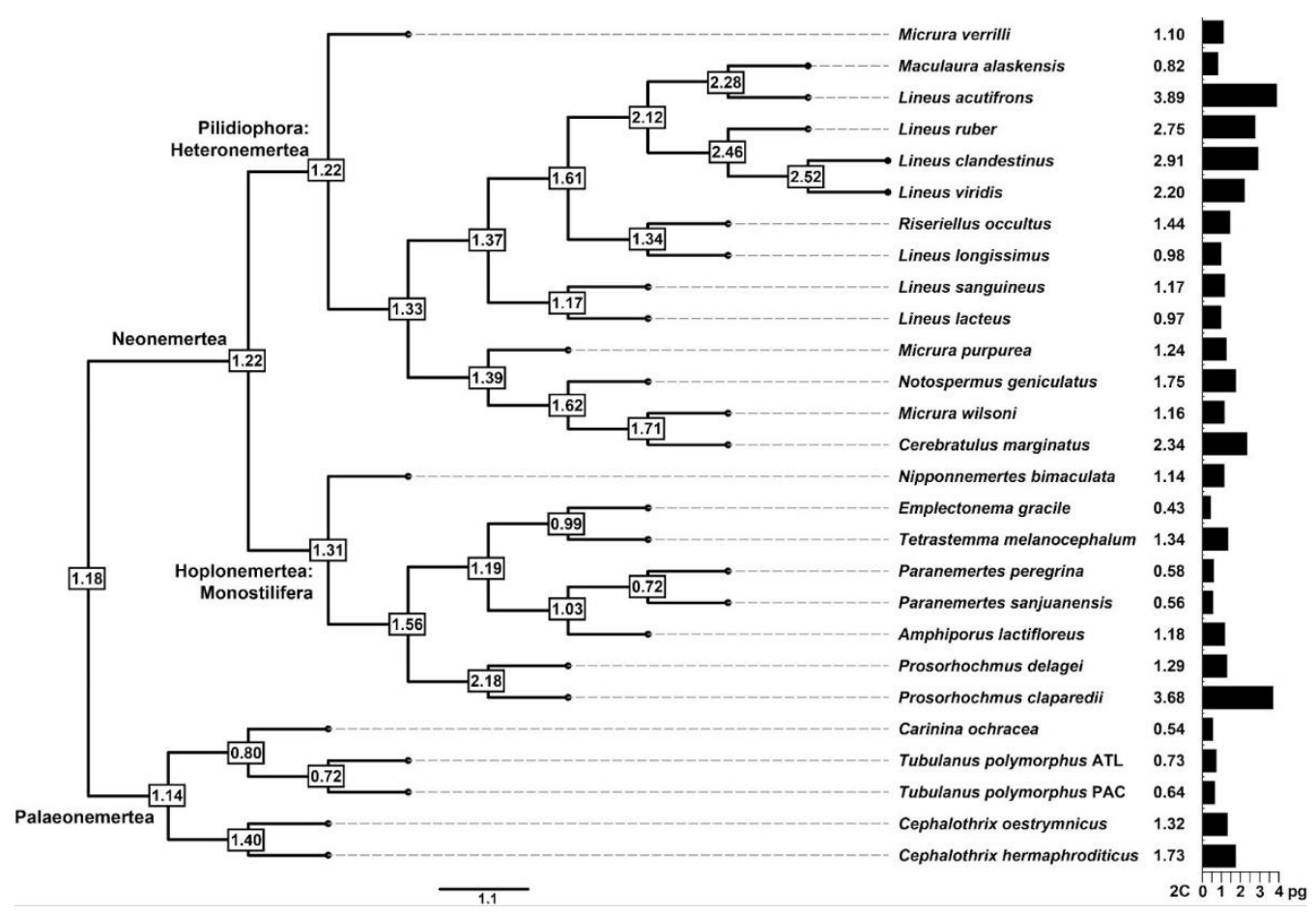

Figure 2. Phylogenetic tree of the studied samples and major nemertean lineages. Genome size $(2 \mathrm{C}(\mathrm{pg}))$ is shown to the right of the tree as a black bar as well as in numerical form. Ancestral reconstruction of genome size for particular nodes is shown in white rectangles.
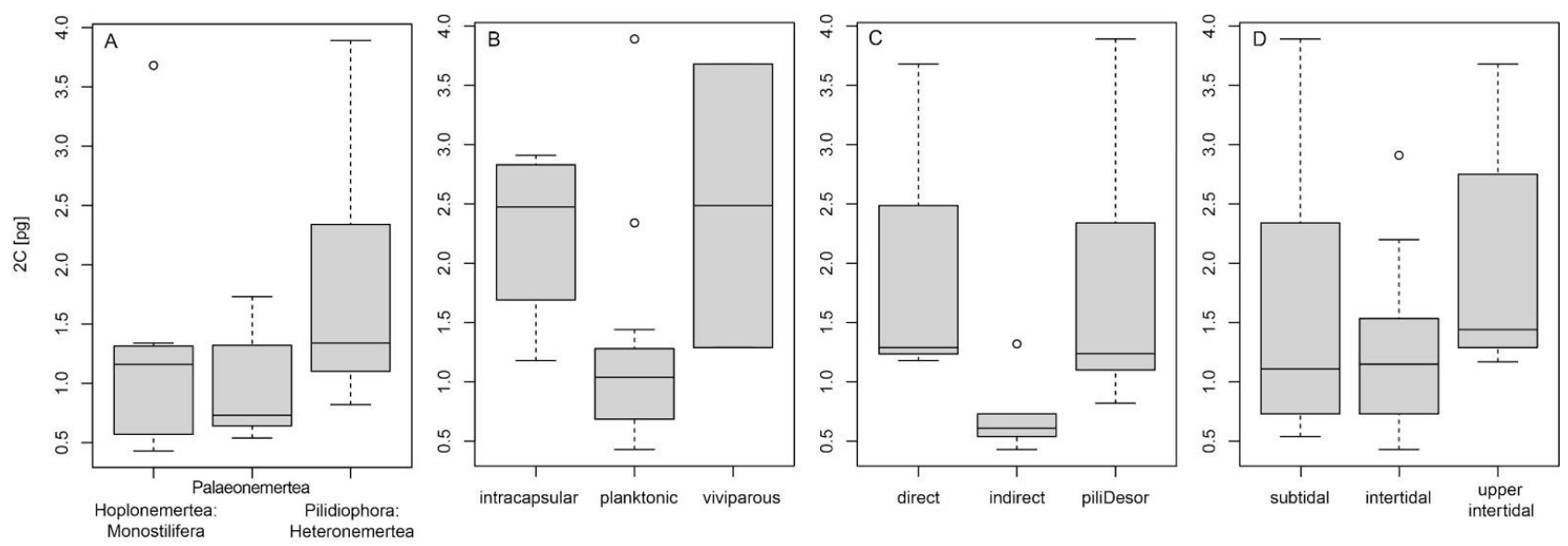

Figure 3. Boxplots of genome sizes (A): across studied lineages of Nemertea, (B): for different reproductive types (dev1), (C): for different developmental types (dev3) and (D): different habitats.

When considering different ecological, reproductive, and developmental types (Supplementary Table S2), significant differences were revealed for the reproductive type (dev1) as well as the developmental type (dev3) using the Kruskall-Wallis test $(p=0.043$ and $p=0.014$, respectively) (Figure 3 ). 
However, the significance of the differences was not confirmed by phylogenetic ANOVA. A weak negative correlation with chromosome number was revealed for the genome size $(r=-0.462)$, although due to the very limited availability of chromosome counts for taxa studied here ( $n=6$, containing two outliers), the correlation was insignificant ( $p=0.518)$. Regarding multiple PGLS regressions, none of the studied morphological characters (mean/max length and mean/max width) were significantly associated with genome size, even after removal of the outliers or log-transformation of the data.

When fitting multi-regime models of trait evolution, different models were suggested for different reproductive, developmental, and ecological traits (Table 2). For the reproductive type (dev1), an OUMV model was proposed as best fitting with higher genome size optima in viviparous and intracapsular developing species than taxa with planktonic larvae. The difference in the rate of stochastic motion was approximately by a factor of 10 among each of the three studied types with the intracapsular type bearing the lowest rate and the viviparous type bearing the highest rate. Concerning larval feeding mode (dev2), the OU1 model was revealed as best fitting, confirming a shared strength of attraction, rate of stochastic motion, as well as optimum genome size for both feeding types. The best fit of BMS for developmental type (dev3) suggested a circa 100 times higher rate of stochastic motion for genome-size evolution of direct and pilidium/Desor larval than for indirect development. Finally, the selection of the OUMV model for $2 \mathrm{C}$ evolution in different habitats revealed that the evolutionary rate $\left(\sigma^{2}\right)$ of genome size in subtidal and upper intertidal is 10 times higher than in the intertidal with different optima in all three habitats.

Table 2. Parameters estimated using best-fitted models of trait evolution for reproductive type (dev1), feeding mode (dev2), developmental type (dev3), and habitat. $\alpha$-strength of attraction towards optimum, $\sigma^{2}$-rate of stochastic motion, $\theta$-optimum value, S.E.—standard error.

\begin{tabular}{ccccc}
\hline Genomic Character/Model & Groups & $\alpha$ & $\boldsymbol{\sigma}^{\mathbf{2}}$ & $\boldsymbol{\theta}$ (S.E.) \\
\hline dev1/OUMV & intracapsular & 0.349 & 0.004 & $2.973(1.150)$ \\
& planktonic & 0.349 & 0.039 & $0.975(0.118)$ \\
dev2/OU1 & viviparous & 0.349 & 0.513 & $5.609(2.978)$ \\
& non-feeding & 0.219 & 0.165 & $1.106(0.267)$ \\
dev3/BMS & feeding & 0.219 & 0.165 & $1.106(0.267)$ \\
& direct & N/A & 0.631 & $1.314(0.418)$ \\
& indirect & N/A & 0.006 & $1.314(0.418)$ \\
habitat/OUMV & larva & N/A & 0.539 & $1.314(0.418)$ \\
& subtidal & 0.305 & 0.191 & $0.437(1.394)$ \\
& intertidal & 0.305 & 0.025 & $1.096(0.097)$ \\
\hline
\end{tabular}

\section{Discussion}

\subsection{Genome Size in Nemertea}

So far, genome size estimates from the phylum Nemertea were known from only ten species and seven genera $[29,50,52]$ out of the approximately 1300 extant species $[1,3]$. With our taxon sampling, we were able to increase the number of investigated nemertean species by 18. The coverage of the species-rich lineages Hoplonemertea and Pilidiophora is more than doubled, and members of the so far omitted cephalotrichid lineage of Palaeonemertea are included. Moreover, we were able to investigate the longest described nemertean species (L. longissimus) and species that are known to populate upper intertidal, almost semi-terrestrial habitats (L. ruber and Prosorhochmus claparedii Keferstein, 1862) [4,42,64]. Additionally, the diversity of developmental modes in the dataset is increased by including directly developing, such as Amphiporus lactifloreus (Johnston, 1828) [65] or viviparous, hermaphroditic species (P. claparedii), and species that have derived larval types (L. ruber and L. viridis) or are mainly reproducing asexually (L. sanguineus) $[14,28,64]$. 


\subsection{Evolutionary Genome Size Dynamics}

Due to the lack of a significant phylogenetic signal, our analyses revealed that the genome size is phylogeny-independent. Ancestral state reconstruction suggested multiple genome expansion and contraction events during the evolution of Nemertea. In Hoplonemertea: Monostilifera, one expansion ( $P$. claparedii) and two contractions (independently in the species of Paranemertes and E. gracile) were observed. Given that the increase in genome size in closely related taxa usually indicates also an increment in the number of chromosomes (e.g., [66]), polyploidy in P. claparedii could be assumed, as the genome size is three times larger when compared to the closely related species Prosorhochmus delagei Oxner, 1907. In the species-rich Pilidiophora: Heteronemertea, there has been at least one (Maculaura alaskensis (Coe, 1901)) but maybe two additional genome contractions (independently in L. longissimus and L. lacteus) and three expansions (independently in L. acutifrons, Cerebratulus marginatus Renier, 1804, and the lineage of Lineus clandestinus Krämer, Schmidt, Podsiadlowski, Beckers, Horn, and von Döhren, 2016, L. ruber, and L. viridis). Interestingly, within our data, no signal for polyploidy among L. sanguineus and L. lacteus was revealed. Polyploidy in these two taxa could be assumed based on the previously published chromosome counts [27]. However, we could not properly assess the correlation of genome size and chromosome numbers in nemerteans due to the very limited availability of chromosome numbers for taxa studied here, and it is theoretically possible that even closely related taxa with different chromosome numbers bear similar genome sizes (e.g., [67]). In Palaeonemertea, two contraction events are suggested (independently in C. ochracea and the species of Tubulanus Renier, 1804), whereas one genome expansion seems to have occurred in C. hermaphroditicus. The possible reasons and drivers for the multiple independent changes in genome size of nemerteans are discussed below. However, it should be noted that there are limitations to ancestral character state reconstructions, as it can not reconstruct genome sizes that are larger or smaller than what is found in the extant species.

\subsection{Body Size and Genome Size}

In several taxa, a significant positive correlation between genome size and body size was found (e.g., [68-71]). This was often explained by the generally positive correlation of genome size and cell size [72] and/or by the strength of the regulation of mitotic division (i.e., determinate growth) [69]. Using new as well as previously published data, no significant correlations of genome size and mean and maximum body length and body width were revealed in Nemertea. The longest described nemertean species, L. longissimus [4] for example, compares in genome size to significantly smaller species of the same clade, such as $M$. alaskensis $[29,34]$. On the other hand, smaller species such as L. ruber and P. claparedii have comparably large genomes, whereas the relatively large palaeonemertean species of the genus Tubulanus have very small genomes [29]. Moreover, the insignificant correlations were revealed also after removal of the body size outlier L. longissimus as well as after $\log$-transformation of the data.

On the one hand, body size estimations in nemerteans are often difficult to assess, as these measures are mostly scored outside their natural habitat where they are rather fragile as well as due to their ability to extremely compress or stretch their bodies. Additionally, it has been demonstrated that species considerably grow even after they have reached sexual maturity; therefore, vastly disparate sizes in different adult specimens of the same species have been recorded e.g., in Riseriellus occultus Rogers, Junoy, Gibson, and Thorpe, 1993 [39]. Accordingly, the size ranges in literature are often rather broad (e.g., 14-80 mm in L. ruber [41,42]; 13-71 $\mathrm{mm}$ in L. viridis [42]). On the other hand, the relationships between genome size and body size, especially in large organisms, should be weaker, as distinct large body size might be more related to cell multiplication than to cell enlargement. Accordingly, we were not able to confirm the previously formulated indication of a positive genome and body size relationship [29]. Nevertheless, other morphological traits might be 
interesting to study in this context as e.g., genome size in crustaceans was shown to relate more to the size of propagules rather than to adult body size [73].

\subsection{Life History and Ecological Traits and Genome Size}

Our analyses showed that the evolution of genome size in Nemerteans is related to reproductive (dev1) and developmental type (dev3) as well as habitat, as differences in several trait evolutionary parameters were revealed.

Our data suggest that the mode of development in nemerteans influenced the evolutionary rate of genome size. Three different developmental modes were included in our dataset under developmental aspect (dev3), direct, indirect (planuliform/decidula larva), and pilidium/Desor-larva. Both direct development and development through pilidium/Desor larvae received about a 100 times higher rate of stochastic motion for genome size evolution than indirect development. Significant differences among developmental types were supported also by the Kruskall-Wallis test. Since indirect development represents the ancestral mode of development in Nemertea, while pilidium/Desor-larva and direct development are derived, the assumption of an elevated evolutionary rate in genome size evolution for the derived developmental modes is intuitive. Unexpectedly, no significant difference in genome size was detected for species with different larval feeding modes (dev2): feeding vs. non-feeding, i.e., lecithotrophic, the latter being the exclusive feeding mode of directly developing species. Thus, the allocation of additional maternal resources for the nourishment of the offspring in lecithotrophic development does not seem to be linked to genome size in the investigated species. The reasons for the significantly larger genomes of directly developing nemertean species (dev3: direct) remain puzzling. Comparative gene-expression studies might help to elucidate if larger genomes are caused by the addition of novel genes with specific functions in direct development or by accumulated non-coding genetic material. However, it has to be noted that all directly developing species also show intracapsular or viviparous development (dev1) and thus developmental variable dev3 might not be independent but just mirrors the effect of dev1 (see below: next paragraph).

An interesting pattern was exhibited for the relationship of developmental aspect (dev1: planktonic, intracapsular, viviparous) or habitat with genome size evolution. The differences between developmental types were significantly supported by the KruskallWallis test. For both dev1 and habitat, three evolutionary optima were modeled, indicating the influence of different selective regimes on genome size to each of the three recorded parameter variants. For developmental aspect dev1, the highest evolutionary optimum was found in viviparous species, which was followed by species with intracapsular and planktonic reproduction. Likewise, the evolutionary optima for habitat revealed decreasing values from upper intertidal to subtidal. The most pronounced example in our dataset is P. claparedii, possessing the largest genome of the investigated hoplonemerteans occupying the most derived habitat (upper intertidal, almost semi-terrestrial). The intertidal heteronemertean species L. ruber, L. viridis, and L. clandestinus have considerably larger genomes than the majority of the closest relatives that dwell in lower intertidal or sublittoral habitats. These results can be straightforwardly interpreted in that the ancestral developmental mode (planktonic) and the ancestral habitat (subtidal) favor smaller genome size, whereas larger genome sizes are selected for in species that have derived developmental modes (intracapsular or viviparous) or live in abiotically more variable habitats (intertidal to upper intertidal).

However, the rates of genome size evolution in these two parameters seem somewhat counterintuitive, since they do not follow the same pattern as the respective evolutionary optima. For both parameters (dev1 and habitat), the most derived state (viviparous and upper intertidal, respectively) shows the highest values of stochastic motion, but in the allegedly ancestral states (planktonic and subtidal, respectively), the values of stochastic motion are not the lowest. Nemerteans with intracapsular reproduction have a 10 times lower rate than found in species with planktonic reproduction, and species found in upper 
intertidal and subtidal habitats have almost 10 times higher evolutionary rate compared to species living in intertidal habitats. Provided that these results are not statistical effects due to sample size but biological phenomena, a possible explanation could lie in effective population size. Due to the lower fecundity in species with intracapsular development or habitat limitations in the intertidal zone, the effective populations of the species could be smaller, which could result in lower genetic variation and, on a larger time-scale, in a lower rate of genome size evolution.

Genome size can change through the expansion of transposable elements (TE), which are genomic copies that are able to increase in numbers [74]. A direct correlation between genome size and the amount of TEs has been observed in some animal groups [75,76]. The mechanisms behind species-specific TE expansions are so far unknown. In some plant species (Hordeum L.), increased drought led to a stress-induced TE activity [77]. Whether the increased genome size optimum as well as higher evolutionary rate are mirroring the higher activity of TEs resulting from the colonization of less favorable semi-terrestrial habitat needs to be further investigated. Alternatively, an increase in genome size by means of polyploidy can be considered, implying the colonization of upper intertidal by polyploid lineages. Polyploidy has been repeatedly suggested for higher adaptive potential, which could be attributed to e.g., the increased genetic variability of polyploids, masking of mutations, gene redundancy, or heterosis (e.g., [78,79]). Based on our dataset, we cannot be fully conclusive about these results. However, we consider that this issue deserves further attention, especially due to the lack of terrestrial and symbiotic species covered in our data.

\subsection{Nemertea and Genomic Biodiversity}

The superphylum Lophotrochozoa includes six lineages: Annelida (17,733 species), Brachiopoda (392 species), Ectoprocta (=Bryozoa, 6,008 species), Mollusca (84,977 species), Nemertea (1358 species), and Phoronida (16 species) [1]. However, genome size estimates are known for about 500 lophotrochozoan species from five of these lineages, which is only about $0.45 \%$ of the known species [51]. The species-rich groups have the greatest genome size ranges, varying between 0.60 and $15.7 \mathrm{pg}(2 \mathrm{C})$ in Mollusca and 0.12 and $15.28 \mathrm{pg}$ in Annelida. However, for both Mollusca and Annelida, there is currently a much higher number of genome size estimates available than in the other clades. Compared to other lineages in Lophotrochozoa, Nemertea displays a relatively narrow genome size range, about the same as Ectoprocta $(0.2 \mathrm{pg}$ to $1.6 \mathrm{pg})$, but larger than in Brachiopoda (0.31 to $0.46 \mathrm{pg})$.

Nemertea is one of the few invertebrate phyla with very limited published genomic data. So far, only one genome has been published [50]. Currently, large sequencing efforts are being directed to understand the genomic biodiversity with the aims of sequencing all life on earth [80]. Animal venoms are a potential source for drug development, medical research, and other applications [81]. As such, genome sequences from Nemertea coupled with proteomics and transcriptomics have the potential for identifying novel toxins and natural products $[82,83]$. Moreover, genome sequences will most probably be able to resolve controversies in nemertean phylogeny such as the Palaeonemertea monophyly, and on deeper timescales, the evolutionary radiation of Lophotrochozoa. Before starting a genome sequencing project, it is valuable to know the size of the genome or at least the range of possible sizes [84]. Hence, our genome size estimates provide valuable data for future genome sequencing projects of this neglected phylum. Due to the variation recovered in this study, future genome sequencing and comparative analyses should also focus on the role of repetitive regions or other phenomena in expanding or contracting genome size. For this, the identification of closely related species with strongly contrasting genome sizes such as M. alaskensis/L. acutifrons or P. delagei/P. claparedii are of key importance.

\subsection{Remarks on Nemertean Taxonomy}

In general, nemertean classification is somewhat chaotic with many genera being polyphyletic. This is especially true for Pilidiophora and likely due to the lack of distinguishing 
morphological characters [85]. The two genera Lineus Sowerby, 1806 and Micrura, for example, are non-monophyletic, as they are scattered throughout the heteronemertean phylogeny.

From the coast near Roscoff in France, two species of Prosorhochmus Keferstein, 1862 have originally been described: the fairly common species $P$. claparedii and the extraordinarily rare species $P$. delagei $[64,86]$. Based on morphological data, $P$. delagei was later synonymized with $P$. claparedii due to the absence of distinguishing diagnostic characters [87]. Since we found specimens that differ in both their genome size and the COI barcoding gene fragment, we conclude that besides the well-characterized P. claparedii, an additional Prosorhochmus species was found in Roscoff. Although only rarely found and never sampled for molecular markers before, we provisionally identify this second species as $P$. delagei.

The species T. polymorphus from the Pacific coast of North America is not identical with the species T. polymorphus collected at the Atlantic coast of Europe [88]. The locality of collection of the Atlantic species is closer to the type locality of T. polymorphus, and the Pacific species has originally been described as Carinella rubra Griffin, 1989. Therefore, the Pacific species should now be named Tubulanus ruber (Griffin, 1898). However, until a detailed revision of the species is published, we refer to either species as T. polymorphus Pacific (the species in [29]) and T. polymorphus Atlantic (the species dealt with herein).

\section{Conclusions}

The genome size estimates increase the available data for nemerteans three-fold and the phylum-wide genome size range increases from almost five-fold to over ninefold. The results shed light on evolutionary and adaptive pressures in nemerteans. Trait analyses show that the highest evolutionary rate is found in upper intertidal, viviparous species with direct development, and the lowest evolutionary rate is found in intertidal species with intracapsular reproduction and indirect development with a planuliform or decidula larva potentially supporting the adaptive hypotheses of genome size evolution. Nemertean genome sequences will allow a deeper investigation of the role of TEs in genome size evolution. Future studies should extend the sampling with terrestrial and symbiotic nemerteans.

Supplementary Materials: The following are available online at https:/ /www.mdpi.com/article/10 .3390/genes12091347/s1, Table S1: Collection history of studied accessions, Table S2: Morphological, ecological, reproductive, and developmental traits of studied nemertean taxa.

Author Contributions: Conceptualization and project administration were done by M.A.N., J.P. and J.v.D., J.P. and C.S. were responsible for investigation; formal analysis and data curation were performed by J.P., M.A.N. and C.S. All co-authors (C.S., J.v.D., J.P., M.A.N.) participated in the provision of resources for the investigation and validated the results. Figures for visualization of the data were prepared by J.P. and M.A.N., J.P. and J.v.D. contributed to funding acquisition and wrote the original draft of the manuscript. Editing and revision of the manuscript were done by M.A.N., J.v.D. and J.P. All authors have read and agreed to the published version of the manuscript.

Funding: This research was funded by the Hessian Ministry of Higher Education, Research, and the Arts through the "LOEWE-Landes-Offensive zur Entwicklung Wissenschaftlich-ökonomischer Exzellenz" programme and the ASSEMBLE+ programme of the European Union, "Evolutionary Developmental Biology of Palaeonemertea" (EvoDevoPal), as well as internal funds of the Senckenberg Research Institute, Frankfurt.

Institutional Review Board Statement: Ethical review and approval were waived for this study, due to the expendability of approval. No vertebrate, cephalopod, or protected species were used in this study.

Informed Consent Statement: Not applicable.

Data Availability Statement: Sequence data are deposited under accession numbers MZ558339MZ558355 at NCBI GenBank (https:/ / www.ncbi.nlm.nih.gov/genbank/ accessed 25 August 2021). 
Acknowledgments: The authors acknowledge T. Bartolomaeus for support in collecting animals and M. Petersen for transport of several specimens from Bonn to Frankfurt am Main and for performing the initial statistical analyses. We are grateful to the staff of the Station de Biologie Marine de Concarneau and the Station Biologique de Roscoff for providing laboratory space, equipment, and consumables for sorting and keeping nemertean specimens during the collecting-trips. We also would like to thank C. Müller for helping to keep specimens alive at the Institute of Evolutionary Biology, University of Bonn and D. Wenzel for assisting C.S. in DNA extraction and sequencing.

Conflicts of Interest: The authors declare no conflict of interest. The funders had no role in the design of the study; in the collection, analyses, or interpretation of data; in the writing of the manuscript, or in the decision to publish the results.

\section{References}

1. Zhang, Z.-Q. Animal biodiversity: An update of classification and diversity in 2013. In: Zhang, Z.-Q. (Ed.) Animal Biodiversity: An Outline of Higher-level Classification and Survey of Taxonomic Richness (Addenda 2013). Zootaxa 2013, 3703, 5-11. [CrossRef]

2. Bleidorn, C. Recent progress in reconstructing lophotrochozoan (spiralian) phylogeny. Org. Divers. Evol. 2019, 19, 557-566. [CrossRef]

3. Kajihara, H.; Chernyshev, A.V.; Sun, S.-C.; Sundberg, P.; Crandall, F.B. Checklist of Nemertean Genera and Species Published between 1995 and 2007. Species Divers. 2008, 13, 245-274. [CrossRef]

4. Gittenberger, A.; Schipper, C. Long live Linnaeus, Lineus longissimus (Gunnerus, 1770) (Vermes: Nemertea: Anopla: Heteronemertea: Lineidae), the longest animal worldwide and its relatives occurring in the Netherlands. Zool. Meded. 2008, 82, 59-63.

5. $\quad$ von Döhren, J.; Bartolomaeus, T. Nemertea. In Guide to the Identification of Marine Meiofauna; Schmidt-Rhaesa, A., Ed.; Pfeil Verlag: Munich, Germany, 2020; pp. 227-238.

6. Gibson, R. Nemertean genera and species of the world: An annotated checklist of original names and description citations, synonyms, current taxonomic status, habitats and recorded zoogeographic distribution. J. Nat. Hist. 1995, 29, 271-561. [CrossRef]

7. Maslakova, S.A. The Invention of the Pilidium Larva in an Otherwise Perfectly Good Spiralian Phylum Nemertea. Integr. Comp. Biol. 2010, 50, 734-743. [CrossRef]

8. Maslakova, S.A.; Hiebert, T.C. From trochophore to pilidium and back again-a larva's journey. Int. J. Dev. Biol. 2014, 58, 585-591. [CrossRef] [PubMed]

9. Thollesson, M.; Norenburg, J.L. Ribbon worm relationships: A phylogeny of the phylum Nemertea. Proc. R. Soc. B Boil. Sci. 2003, 270, 407-415. [CrossRef]

10. Andrade, S.C.S.; Montenegro, H.; Strand, M.; Schwartz, M.L.; Kajihara, H.; Norenburg, J.L.; Turbeville, J.M.; Sundberg, P.; Giribet, G. A Transcriptomic Approach to Ribbon Worm Systematics (Nemertea): Resolving the Pilidiophora Problem. Mol. Biol. Evol. 2014, 31, 3206-3215. [CrossRef] [PubMed]

11. Andrade, S.; Strand, M.; Schwartz, M.L.; Chen, H.; Kajihara, H.; Von Döhren, J.; Sun, S.; Junoy, J.; Thiel, M.; Norenburg, J.L.; et al. Disentangling ribbon worm relationships: Multi-locus analysis supports traditional classification of the phylum Nemertea. Cladistics 2011, 28, 141-159. [CrossRef]

12. Kvist, S.; Laumer, C.E.; Junoy, J.; Giribet, G. New insights into the phylogeny, systematics and DNA barcoding of Nemertea. Invertebr. Syst. 2014, 28, 287-308. [CrossRef]

13. Thiel, M.; Junoy, J. Mating behavior of nemerteans: Present knowledge and future directions. J. Nat. Hist. 2006, 40, 1021-1034. [CrossRef]

14. von Döhren, J. Nemertea. Evolutionary Developmental Biology of Invertebrates Vol. 2: Lophotrochozoa (Spiralia); Wanninger, A., Ed.; Springer: Wien, Austria, 2015; pp. 155-192.

15. Zattara, E.E.; Fernández-Álvarez, F.A.; Hiebert, T.C.; Bely, A.E.; Norenburg, J.L. A phylum-wide survey reveals multiple independent gains of head regeneration in Nemertea. Proc. R. Soc. B Boil. Sci. 2019, 286, 20182524. [CrossRef] [PubMed]

16. Von Döhren, J. The fate of the larval epidermis in the Desor-larva of Lineus viridis (Pilidiophora, Nemertea) displays a historically constrained functional shift from planktotrophy to lecithotrophy. Zoomorphology 2011, 130, 189-196. [CrossRef]

17. Gregory, T.R. Coincidence, coevolution, or causation? DNA content, cellsize, and the C-value enigma. Biol. Rev. 2007, 76, 65-101. [CrossRef]

18. Lynch, M.; Conery, J.S. The Origins of Genome Complexity. Science 2003, 302, 1401-1404. [CrossRef]

19. Petrov, D.A. Mutational Equilibrium Model of Genome Size Evolution. Theor. Popul. Biol. 2002, 61, 531-544. [CrossRef] [PubMed]

20. Gregory, T. Insertion-deletion biases and the evolution of genome size. Gene 2004, 324, 15-34. [CrossRef] [PubMed]

21. Sun, C.; Arriaza, J.R.L.; Mueller, R.L. Slow DNA Loss in the Gigantic Genomes of Salamanders. Genome Biol. Evol. 2012, 4, 1340-1348. [CrossRef] [PubMed]

22. Kapusta, A.; Suh, A.; Feschotte, C. Dynamics of genome size evolution in birds and mammals. Proc. Natl. Acad. Sci. USA 2017, 114, E1460-E1469. [CrossRef]

23. Gregory, T. The Bigger the C-Value, the Larger the Cell: Genome Size and Red Blood Cell Size in Vertebrates. Blood Cells Mol. Dis. 2001, 27, 830-843. [CrossRef] 
24. Gregory, T.R.; Johnston, J.S. Genome size diversity in the family Drosophilidae. Heredity 2008, 101, 228-238. [CrossRef] [PubMed]

25. Andrews, C.B.; MacKenzie, S.A.; Gregory, T.R. Genome size and wing parameters in passerine birds. Proc. R. Soc. B Boil. Sci. 2008, 276, 55-61. [CrossRef]

26. Wright, N.A.; Gregory, T.R.; Witt, C. Metabolic 'engines' of flight drive genome size reduction in birds. Proc. R. Soc. B Boil. Sci. 2014, 281, 20132780. [CrossRef] [PubMed]

27. Chen, H.; Liu, K.; Sun, S. Karyotype analysis of four nemertean species. Chin. J. Oceanol. Limnol. 2009, 27, 748-752. [CrossRef]

28. Ament-Velásquez, S.L.; Figuet, E.; Ballenghien, M.; Zattara, E.E.; Norenburg, J.; Fernández-Álvarez, F.; Bierne, J.; Bierne, N.; Galtier, N. Population genomics of sexual and asexual lineages in fissiparous ribbon worms (Lineus, Nemertea): Hybridization, polyploidy and the Meselson effect. Mol. Ecol. 2016, 25, 3356-3369. [CrossRef] [PubMed]

29. Mulligan, K.L.; Hiebert, T.C.; Jeffery, N.W.; Gregory, T.R. First estimates of genome size in ribbon worms (phylum Nemertea) using flow cytometry and Feulgen image analysis densitometry. Can. J. Zool. 2014, 92, 847-851. [CrossRef]

30. Bartolomaeus, T.; Von Döhren, J. Comparative morphology and evolution of the nephridia in Nemertea. J. Nat. Hist. 2010, 44, 2255-2286. [CrossRef]

31. Stricker, S.A. Phylum Nemertea. In Reproduction and Development of Marine Invertebrates of the Northern Pacific Coast; Strathmann, M.F., Ed.; University of Washington Press: Seattle, WA, USA, 1987; pp. 129-137.

32. Maslakova, S.A.; von Döhren, J. Larval development with transitory epidermis in Paranemertes peregrina and other hoplonemerteans. Biol. Bull. 2009, 216, 273-292. [CrossRef]

33. Hiebert, T.C.; Maslakova, S.A. Larval Development of Two N. E. Pacific Pilidiophoran Nemerteans (Heteronemertea; Lineidae). Biol. Bull. 2015, 229, 265-275. [CrossRef]

34. Hiebert, T.C.; Maslakova, S. Integrative Taxonomy of the Micrura alaskensisCoe, 1901 Species Complex (Nemertea: Heteronemertea), with Descriptions of a New GenusMaculauragen. nov. and Four New Species from the NE Pacific. Zool. Sci. 2015, 32, 615-637. [CrossRef]

35. Stricker, S.A. The Morphology of Paranemertes sanjuanensis sp.n. (Nemertea, Monostilifera) from Washington, U.S.A. Zool. Scr. 1982, 11, 107-115. [CrossRef]

36. Riser, N.W. New Zealand nemertines from kelp holdfasts: Heteronemertinea II. Notospermus geniculatus (Delle Chiaje, 1828) n. comb. New Zealand J. Zool. 1991, 18, 427-438. [CrossRef]

37. Junoy, J.; Gibson, R. A new species of Procephalothrix (Anopla, Archinemertea) from North-Western Spain (Nemertea). Zool. Anz. 1991, 226, 185-194.

38. Sundberg, P.; Chernyshev, A.V.; Kajihara, H.; Kånneby, T.; Strand, M. Character-matrix based descriptions of two new nemertean (Nemertea) species. Zool. J. Linn. Soc. 2009, 157, 264-294. [CrossRef]

39. Beckers, P.; Bartolomaeus, T.; Von Döhren, J. Observations and Experiments on the Biology and Life History of Riseriellus occultus (Heteronemertea: Lineidae). Zool. Sci. 2015, 32, 531-546. [CrossRef]

40. Von Döhren, J. First record on the development of the larva of the basally branching nemertean species Carinina ochracea (Palaeonemertea). Helgol. Mar. Res. 2016, 70, 141. [CrossRef]

41. Gibson, R.; Knight-Jones, E.W. Flatworms and Ribbon Worms. In Handbook of the Marine Fauna of North-West Europe; Hayward, P.J., Ryland, J.S., Eds.; Oxford University Press: Oxford, UK, 2017; pp. 133-164.

42. Krämer, D.; Schmidt, C.; Podsiadlowski, L.; Beckers, P.; Horn, L.; Von Döhren, J. Unravelling the Lineus ruber/viridis species complex (Nemertea, Heteronemertea). Zool. Scr. 2016, 46, 111-126. [CrossRef]

43. Von Döhren, J.; Bartolomaeus, T. Unexpected ultrastructure of an eye in Spiralia: The larval ocelli of Procephalothrix oestrymnicus (Nemertea). Zoomorphology 2018, 137, 241-248. [CrossRef]

44. Sagorny, C.; Wesseler, C.; Krämer, D.; Von Döhren, J. Assessing the diversity and distribution of Cephalothrix species (Nemertea: Palaeonemertea) in European waters by comparing different species delimitation methods. J. Zool. Syst. Evol. Res. 2019, 57, 497-519. [CrossRef]

45. Greilhuber, J. The Origin, Evolution and Proposed Stabilization of the Terms 'Genome Size' and 'C-Value' to Describe Nuclear DNA Contents. Ann. Bot. 2005, 95, 255-260. [CrossRef] [PubMed]

46. Otto, F. DAPI staining of fixed cells for high-resolution flow cytometry of nuclear DNA. In Methods in Cell Biology; Vol. 33 Flow Cytometry; Darzynkiewicz, Z., Crissman, H.A., Eds.; Elsevier: Amsterdam, The Netherlands, 1990; pp. 105-110.

47. Dolezel, J.; Doleželová, M.; Novák, F.J. Flow cytometric estimation of nuclear DNA amount in diploid bananas (Musa acuminata and M. balbisiana). Biol. Plant. 1994, 36, 351-357. [CrossRef]

48. Doležel, J.; Greilhuber, J.; Lucretti, S.; Meister, A.; Lysák, M.A.; Nardi, L.; Obermayer, R. Plant Genome Size Estimation by Flow Cytometry: Inter-laboratory Comparison. Ann. Bot. 1998, 82, 17-26. [CrossRef]

49. Doležel, J.; Bartoš, J.; Voglmayr, H.; Greilhuber, J. Letter to the editor. Cytometry 2003, 51, 127-128. [CrossRef]

50. Luo, Y.-J.; Kanda, M.; Koyanagi, R.; Hisata, K.; Akiyama, T.; Sakamoto, H.; Sakamoto, T.; Satoh, N. Nemertean and phoronid genomes reveal lophotrochozoan evolution and the origin of bilaterian heads. Nat. Ecol. Evol. 2017, 2, 141-151. [CrossRef]

51. Gregory, T.R. Animal Genome Size Database. Available online: http:/ / www.genomesize.com (accessed on 25 August 2011).

52. Goldberg, R.B.; Crain, W.R.; Ruderman, J.V.; Moore, G.P.; Barnett, T.R.; Higgins, R.C.; Gelfand, R.A.; Galau, G.A.; Britten, R.J.; Davidson, E.H. DNA sequence organization in the genomes of five marine invertebrates. Chromosoma 1975, 51, $225-251$. [CrossRef] 
53. Folmer, O.; Black, M.; Hoeh, W.; Lutz, R.; Vrijenhoek, R. DNA primers for amplification of mitochondrial cytochrome c oxidase subunit I from diverse metazoan invertebrates. Mol. Mar. Boil. Biotechnol. 1994, 3, 294-299.

54. Edgar, R.C. MUSCLE: Multiple sequence alignment with high accuracy and high throughput. Nucleic Acids Res. 2004, 32, 1792-1797. [CrossRef]

55. Larsson, A. AliView: A fast and lightweight alignment viewer and editor for large datasets. Bioinformatics 2014, 30, 3276-3278. [CrossRef]

56. Nguyen, L.-T.; Schmidt, H.; Von Haeseler, A.; Minh, B.Q. IQ-TREE: A Fast and Effective Stochastic Algorithm for Estimating Maximum-Likelihood Phylogenies. Mol. Biol. Evol. 2014, 32, 268-274. [CrossRef]

57. Trifinopoulos, J.; Nguyen, L.-T.; Von Haeseler, A.; Minh, B.Q. W-IQ-TREE: A fast online phylogenetic tool for maximum likelihood analysis. Nucleic Acids Res. 2016, 44, W232-W235. [CrossRef] [PubMed]

58. Kalyaanamoorthy, S.; Minh, B.Q.; Wong, T.; Von Haeseler, A.; Jermiin, L.S. ModelFinder: Fast model selection for accurate phylogenetic estimates. Nat. Methods 2017, 14, 587-589. [CrossRef] [PubMed]

59. Venables, W.N.; Ripley, B.D. Package MASS. Available online: http:/ / www.r-project.org (accessed on 17 October 2012).

60. Revell, L.J. phytools: An R package for phylogenetic comparative biology (and other things). Methods Ecol. Evol. 2011, 3, 217-223. [CrossRef]

61. Beaulieu, J.M.; Jhwueng, D.-C.; Boettiger, C.; O’Meara, B. Modeling stabilizing selection: Expanding The Ornstein-Uhlenbeck model of adaptive evolution. Evolution 2012, 66, 2369-2383. [CrossRef]

62. Grafen, A. The phylogenetic regression. Philos. Trans. R. Soc. B Biol. Sci. 1989, 326, 119-157. [CrossRef]

63. Orme, D.; Freckleton, R.; Thomas, G.; Petzoldt, T.; Fritz, S.; Isaac, N.; Pearse, W. Caper: Comparative analyses of phylogenetics and evolution in R. R Packag version 0.5. Proc. R. Soc. B. 2012, 2, 458.

64. Maslakova, S.A.; Norenburg, J.L. Revision of the smiling worms, genus Prosorhochmus Keferstein, 1862, and description of a new species, Prosorhochmus belizeanus sp. nov. (Prosorhochmidae, Hoplonemertea, Nemertea) from Florida and Belize. J. Nat. Hist. 2008, 42, 1219-1260. [CrossRef]

65. von Döhren, J.; University of Bonn, Bonn, Germany. Personal communication, 2021.

66. Du, Y.-P.; Bi, Y.; Zhang, M.-F.; Yang, F.-P.; Jia, G.-X.; Zhang, X.-H. Genome Size Diversity in Lilium (Liliaceae) Is Correlated with Karyotype and Environmental Traits. Front. Plant Sci. 2017, 8, 1303. [CrossRef] [PubMed]

67. Pierce, B.A.; Mitton, J.B. The Relationship Between Genome Size and Genetic Variation. Am. Nat. 1980, 116, 850-861. [CrossRef]

68. Gregory, T.R.; Hebert, P.; Kolasa, J. Evolutionary implications of the relationship between genome size and body size in flatworms and copepods. Heredity 2000, 84, 201-208. [CrossRef]

69. Jeffery, N.W.; Ellis, E.A.; Oakley, T.H.; Gregory, T.R. The Genome Sizes of Ostracod Crustaceans Correlate with Body Size and Evolutionary History, but not Environment. J. Hered. 2017, 108, 701-706. [CrossRef]

70. Wyngaard, G.A.; Rasch, E.M. Patterns of genome size in the copepoda. Hydrobiologia 2000, 417, 43-56. [CrossRef]

71. Wyngaard, G.A.; Rasch, E.M.; Manning, N.M.; Gasser, K.; Domangue, R. The relationship between genome size, development rate, and body size in copepods. Hydrobiologia 2005, 532, 123-137. [CrossRef]

72. Cavalier-Smith, T. Skeletal DNA and the Evolution of Genome Size. Annu. Rev. Biophys. Bioeng. 1982, 11, 273-302. [CrossRef] [PubMed]

73. Glazier, D. Genome Size Covaries More Positively with Propagule Size than Adult Size: New Insights into an Old Problem. Biology 2021, 10, 270. [CrossRef] [PubMed]

74. Bourque, G.; Burns, K.H.; Gehring, M.; Gorbunova, V.; Seluanov, A.; Hammell, M.; Imbeault, M.; Izsvák, Z.; Levin, H.L.; Macfarlan, T.S.; et al. Ten things you should know about transposable elements. Genome Biol. 2018, 19, 1-12. [CrossRef]

75. Talla, V.; Suh, A.; Kalsoom, F.; Dincă, V.; Vila, R.; Friberg, M.; Wiklund, C.; Backström, N. Rapid Increase in Genome Size as a Consequence of Transposable Element Hyperactivity in Wood-White (Leptidea) Butterflies. Genome Biol. Evol. 2017, 9, $2491-2505$. [CrossRef] [PubMed]

76. Naville, M.; Henriet, S.; Warren, I.; Sumic, S.; Reeve, M.; Volff, J.-N.; Chourrout, D. Massive Changes of Genome Size Driven by Expansions of Non-autonomous Transposable Elements. Curr. Biol. 2019, 29, 1161-1168. [CrossRef]

77. Kalendar, R.; Tanskanen, J.; Immonen, S.; Nevo, E.; Schulman, A.H. Genome evolution of wild barley (Hordeum spontaneum) by BARE-1 retrotransposon dynamics in response to sharp microclimatic divergence. Proc. Natl. Acad. Sci. USA 2000, 97, 6603-6607. [CrossRef]

78. Comai, L. The advantages and disadvantages of being polyploid. Nat. Rev. Genet. 2005, 6, 836-846. [CrossRef] [PubMed]

79. Finigan, P.; Tanurdzic, M.; Martienssen, R.A. Origins of Novel Phenotypic Variation in Polyploids. In Polyploidy and Genome Evolution; Springer: Berlin, Heidelberg, 2012; pp. 57-76. [CrossRef]

80. Lewin, H.A.; Robinson, G.E.; Kress, W.J.; Baker, W.J.; Coddington, J.A.; Crandall, K.A.; Durbin, R.; Edwards, S.V.; Forest, F.; Gilbert, M.; et al. Earth BioGenome Project: Sequencing life for the future of life. Proc. Natl. Acad. Sci. USA 2018, 115, 4325-4333. [CrossRef] [PubMed]

81. Drukewitz, S.H.; Von Reumont, B.M. The Significance of Comparative Genomics in Modern Evolutionary Venomics. Front. Ecol. Evol. 2019, 7, 163. [CrossRef]

82. Göransson, U.; Jacobsson, E.; Strand, M.; Andersson, H.S. The Toxins of Nemertean Worms. Toxins 2019, 11, 120. [CrossRef] [PubMed] 
83. Von Reumont, B.M.; Lüddecke, T.; Timm, T.; Lochnit, G.; Vilcinskas, A.; Von Döhren, J.; Nilsson, M.A. Proteo-Transcriptomic Analysis Identifies Potential Novel Toxins Secreted by the Predatory, Prey-Piercing Ribbon Worm Amphiporus lactifloreus. Mar. Drugs 2020, 18, 407. [CrossRef] [PubMed]

84. Li, F.-W.; Harkess, A. A guide to sequence your favorite plant genomes. Appl. Plant Sci. 2018, 6, e1030. [CrossRef]

85. Schwartz, M.L.; Norenburg, J.L. Can we infer heteronemertean phylogeny from available morphological data? Hydrobiologia 2001, 456, 165-174. [CrossRef]

86. Cornet, R.; Marche-Marchad, I. Inventaire de la faune Marine de Roscoff. In Travaux de la Station Biologique de Roscoff; Presses Universitaires de France: Paris, France, 1955; Volume 7, pp. 1-15.

87. Gibson, R.; Moore, J. The genus Prosorhochmus Keferstein, 1862 (Hoplonemertea). J. Zool. 1985, 206, 145-162. [CrossRef]

88. Krämer, D.; University of Bonn, Bonn, Germany. Personal communication, 2017. 